\title{
Entrepreneurial Intentions of Undergraduate Students in Yemen: Applying the Theory of Planned Behaviour
}

\author{
Al-Qadasi Nabil Abdullah Abdo Saeed ${ }^{1 *} \quad$ Zhang Gongyi $^{1} \quad$ Tesfaye Getachew Charkos ${ }^{2}$ \\ 1.School of Management, Jilin University, PO box 130022, Changchun, Jilin, China \\ 2.School of Public Health, Jilin University, PO box 130021, Changchun, Jilin, China
}

\begin{abstract}
The intention of undergraduate students towards entrepreneurial was not yet studied in Yemen. We aimed to study the intentions of undergraduate students towards an entrepreneurial activity. The cross-sectional study design was used. This study was used the questionnaire developed to test theory of planned behavioral in the field of entrepreneurship. The Cronbach's alpha test was used to test the reliability. Pearson correlation analysis was used to assess the relationship between study variables. Multiple regression models were applied. All analysis was performed with SPSS. A total of 432 undergraduate students included from the Sana'a University in Yemen. Out of this, $74.5 \%$ was male students and $25.5 \%$ were female students. The results of correlation test indicate that entrepreneurial intentions have a strong positive correlation with personal attitude $(r=.917)$, subjective norms $(r=0.963)$ and perceived behavioral $(r=0.955)$. A statistically significant association was found between perceived behavioral control $(\beta=0.420, \mathrm{p}<0.001)$, subjective norms $(\beta=0.524, \mathrm{p}<0.001)$ and the intention to start a business. However, non-significant association was found between personal attitude and entrepreneurial intention $(\beta=-0.040 ; p<0.169)$. Our study suggested that providing entrepreneurial capabilities among citizens, may improve societal norms and individual attitudes toward entrepreneurship. However, we could not found a statistically significant association between attitude and entrepreneurial intention.
\end{abstract}

Keywords: Entrepreneurial intention, Undergraduate students, Yemen, Theory of Planned Behaviour

DOI: $10.7176 / E J B M / 11-35-04$

Publication date: December $31^{\text {st }} 2019$

\section{Introduction}

Entrepreneurship is a key factor for economic development; it is perceived as super important for the advancement of economic growth both in developed and emerging economies (Stel et al., 2005). It has been recognized as a strategy to enhance employment and job creation for young people and as a vital factor to the country's economic stability (Alessandro A. et al., 2016; Maria and Allam, 2018; Reyad et al., 2018; Debus et al., 2017; Adusei, 2016). In developed and developing countries, the expansion of small-medium and micro enterprises (SMMEs) as mechanisms to which it can create new job opportunities, improve economic growth and equity in the country (Malebana, 2014). An entrepreneurship education has increased due to the need to prepare students for coping in contemporary work and living environment (Sharaf et al., 2018).

This study examined the subjective norms within Yemen higher education community in terms of favorability to entrepreneurial activities. Understanding factors that shape entrepreneurial intention among public universities' students to become entrepreneurs correct any misconceptions that university students might have about starting a new business and promote a very highly favorable environment for entrepreneurial activities. In addition, the study seeks to measure the level of university students' intention and to study their relationships with students' personal attraction toward becoming an entrepreneur, perceived behavioral control and subjective norms of entrepreneurship.

\section{Literature Review and Hypotheses Formulation}

The Theory of Planned Behaviour (TPB) model has been identified within international research as one of the most promising approaches for understanding entrepreneurial intention and decisions. According to the TPB model, entrepreneurial intention antecedents which effect to create a new venture are (attitudes, subjective norms and perceived behavioral control). This section provides a review of the most important literature relating to the structure of this study.

\subsection{Entrepreneurial Intention}

The studies use entrepreneurial intention as a tool for measuring the level of entrepreneurship activity. (Ajzen, 1991) developed the Theory of Planned Behaviour TPB as a psychological model to predict planned behavior. In his model, suggests three motivational factors influence entrepreneurial intention (personal attitudes towards entrepreneurship and social subjective norms as well as perceived entrepreneurial capability). The TPB has during recent years become one of the main theoretical models frequently used to explain and predict human behavior (Ajzen, 2012; Liñán and Fayolle, 2015).

Entrepreneurial intention has been defined in different ways, as the intention of a person to set up a new 
business venture in the future (Thompson, 2009), the intention to own a business (Crant, 1996), the intention to be self-employed (Douglas and Shepherd, 2002). Entrepreneurial intention has a psychological nature, the intention has proven as the best predictor of an individual's planned behavior, especially when the behavior is rare and hard to observe or involves an unpredictable amount of time (Krueger et al., 2000). In our context, we can define entrepreneurial intention as any person who willing or plans to set-up a new venture for the main purpose of profit earning and growth at some point in the future.

\subsection{Attitude toward Entrepreneurship and Entrepreneurial Intention}

Attitude toward behaviour refers to the degree to which an individual has a favorable or unfavorable evaluation of the behaviour in question (Ajzen, 1991). Several studies identified a number of positive expected, or valued, outcomes of entrepreneurial behavior such as valuation of money, autonomy, authority, challenge, change, personal satisfaction and personal quality of life (Davidsson, 1995; Kolvereid and Isaksen, 2006; Krueger et al., 2000; Schwarz et al., 2009; Zhang et al., 2015). Based on the findings of these studies, individuals are more likely to view entrepreneurship as a viable career choice. Thus, we hypothesize:

H1: the stronger the level of personal attitude towards entrepreneurship is, the higher the level of entrepreneurial intention will be.

\subsection{Perceived Subjective Norms and Entrepreneurial Intention}

Subjective/social norm is the most important factor of TPB, which refer to the perceived social and cultural pressure felt by an individual to perform or not perform a specific behavior (Kolvereid, 1996). Several studies find a significant relationship between subjective norms and entrepreneurial intention (Engle, et al, 2010; Moriano et al., 2012; Shah and Soomor, 2017; AL-Shammari and Weleed, 2018) in contrast, other studies do not support this finding (Krueger et al., 2000; Liñán and Chen, 2009) Thus, the second hypothesis would be: $\mathrm{H} 2$ : subjective norms are positively associated with entrepreneurial intention.

\subsection{Perceived Behavioral Control and Entrepreneurial Intention}

The third antecedent of entrepreneurial intention is perceived behavioural control (PBC). (Ajzen, 1991), explains perceived behavioural control as the perceived ease or difficulty of performing the behaviour and it is assumed to reflect past experience as well as expected obstacles and difficulties. In the field of entrepreneurship, it is termed entrepreneurial self-efficacy (ESE). According to (Malebana, 2017), ESE defined as the degree to which individuals believe they have the ability in relation to new venture creation.

The individual who facing a specific opportunity he/she asking himself "could I do it?" those with entrepreneurial education, experience or prior exposure may perceive themselves as more capable to exploit and seize the opportunities. The Findings of prior empirical studies indicates that the higher the perceived behavioural control to new venture creation, the higher the level of business startup intention (Van Gelderen et al., 2008; Liñán et al., 2011; AL-Shammari and Weleed, 2018). Thus, the following hypothesis is proposed: H3: perceived behavioural control is positively associated with entrepreneurial intention.

\section{Methodology and Procedures}

The study adopted cross-sectional study design. The sample for this study was taken from Sanaa'a university students in Yemen. Data were gathered in April 2019 using a set of questionnaire measuring students' demographic information (such as: age, gender), field of the study, personal attitudes, perceived behavioral control, subjective norms and entrepreneurial intention of the undergraduate students. Permissions to conduct the research were obtained from Vice Chancellor of each university and also the Dean of the selected faculties. Data were collected by the researcher and two research assistants who had been trained to properly conduct a good quality research. The respondents was selected using simple random sampling technique.

This study was used the questionnaire developed to test theory of planned behavioral in the field of entrepreneurship (Liñán and Chen, 2009; Liñán et al., 2011). The questionnaire has two sections, the demographic information (age, gender and field of study) and items targeting the purpose of the study. In total 20 items were included in the second section, with the following scales: a) measures of entrepreneurial intention with 6 items, b) measures of attitude towards entrepreneurship with 5 items, c) measures of subjective norms with 3 items, and d) measures of perceived behavioral control with 6 items. These items are measured using a five-point Likert scales $1=$ (strongly disagree); $5=$ (strongly agree). Sample size was determined using (Yamane, 1967).

Descriptive statistics was used to calculate the mean and percentage of the students. In this study, the Cronbach's alpha test was used to test the reliability of the research instrument (Bujang et al., 2018). Cronbach's alpha value of 0.70 or above implies strong scale reliability. Pearson correlation analysis was used to assess the direction and strength of the relationship between all study variables. Multiple regression models were used to test the linear relationship between the entrepreneurial intention and predictors (Wiedermann and von Eye, 2015). 
All analysis was performed with SPSS and p-value $<0.05$ was considered as statistically significant.

\section{Results}

\subsection{Respondents demographic characteristics}

This study included 432 undergraduate students studying at Sana'a University. The response rate was $87.8 \%$. From the total sample, $74.5 \%$ were male students and $25.5 \%$ were female students. Out of this, $56.7 \%$ were from business administration programmes and $42.3 \%$ were non-business such as engineering, computer and IT, law and agriculture. The participants average age was 22.57 (ranged from 20 to 31) years old (Table 1).

Table 1| Respondent's demographic variables

\begin{tabular}{|c|c|c|c|c|}
\hline Variable & - & Mean & Frequency & Percentage \\
\hline Age & & 22.57 & & \\
\hline \multirow[t]{2}{*}{ Gender } & Male & & 322 & 74.5 \\
\hline & Female & & 110 & 25.5 \\
\hline \multirow[t]{2}{*}{ Field of study } & Business & & 244 & 56.5 \\
\hline & Non-Business & & 188 & 43.5 \\
\hline
\end{tabular}

\subsection{Reliability Test}

In this study, the reliability of the measuring instrument was tested by means of Cronbach's alpha. The reliability tests for the internal consistency of entrepreneurial intention, personal attitude, perceived behavioural control and subjective norms the Cronbach's Alpha scores were 0.984, 0.862, 0.973, and 0.971 respectively (see Table 2).

Table 2| Factor and reliability analyses for constructs

\begin{tabular}{|c|c|c|c|c|}
\hline \multirow{2}{*}{ Items } & \multicolumn{4}{|c|}{ Factor loading } \\
\hline & 1 & 2 & 3 & 4 \\
\hline \multicolumn{5}{|l|}{ Entrepreneurial intention } \\
\hline I am ready to do anything to be an entrepreneur & .979 & & & \\
\hline My professional goal is to become an entrepreneur & .982 & & & \\
\hline I will make every effort to stat an run my own business & .980 & & & \\
\hline I am determined to create a business in the future & .982 & & & \\
\hline I have very seriously thought of starting a business & .980 & & & \\
\hline I have the business intention to start a business some day & .984 & & & \\
\hline \multicolumn{5}{|l|}{ Personal attitude } \\
\hline $\begin{array}{l}\text { Being an entrepreneur implies more advantages than disadvantages to } \\
\text { me }\end{array}$ & & .972 & & \\
\hline A career as entrepreneur is attractive for me & & .783 & & \\
\hline If I had the opportunity and resource, I would like to start a business & & .788 & & \\
\hline Being an entrepreneur would give me great satisfaction & & .782 & & \\
\hline Among various options, I would rather be an entrepreneur & & .779 & & \\
\hline \multicolumn{5}{|l|}{ Perceived behavioral control } \\
\hline To start a business and keep it working would be easy for me & & & .967 & \\
\hline I am prepared to start a viable business & & & .964 & \\
\hline I am able to control the creation process of a new business & & & .965 & \\
\hline I know the necessary practical details needed to start a business & & & .971 & \\
\hline I know how to develop an entrepreneur project & & & .968 & \\
\hline If I try to start a business, I would have a high probability of succeeding & & & .971 & \\
\hline \multicolumn{5}{|l|}{ Subjective norms } \\
\hline My immediate family would approve of my decision to start a business & & & & .955 \\
\hline My friends would approve of me decision to start a business & & & & .963 \\
\hline My colleagues/peers would approve of my diction to start a business & & & & .954 \\
\hline Cronbach's alpha & 0.984 & 0.862 & 0.973 & 0.971 \\
\hline
\end{tabular}

\subsection{The Correlation analysis across the variable}

The correlations among the variables are shown in (Table 3). The results revealed that significantly positive and negative correlations among control variables and antecedents of entrepreneurial intention and entrepreneurial intention. Entrepreneurial intention has a positive non-significant correlation with age $(r=0.022)$ and negative non-significant correlation with gender $(r=-0.21)$, but a positive non-significant correlation for field of study $(r$ $\left.=.047^{* *}\right)$. Entrepreneurial intentions have a strong positive correlation with personal attitude $\left(r=.917^{* *}\right)$, Perceived behavioral $\left(r=.955^{* *}\right)$ and Subjective norms $\left(r=.963^{*}\right)$ 
Table 3| Descriptive statistics analysis for correlations among variables

\begin{tabular}{|c|c|c|c|c|c|c|c|c|c|c|}
\hline$\#$ & Variable & Mean & SD & 1 & 2 & 3 & 4 & 5 & 6 & 7 \\
\hline 1 & Age & 22.57 & 1.770 & 1.00 & & & & & & \\
\hline 2 & Gender & - & - & -0.21 & 1.00 & & & & & \\
\hline 3 & Field of study & - & - & $462^{* *}$ & .012 & 1.00 & & & & \\
\hline 4 & Personal attitude & 3.13 & .855 & .028 & -.018 & .043 & 1.00 & & & \\
\hline 5 & Subjective norms & 3.07 & 1.06 & .070 & .000 & $.122^{*}$ & $.924^{* *}$ & 1.00 & & \\
\hline 6 & Perceived behavioral & 2.83 & .987 & -.012 & -.001 & -.054 & $.923^{* *}$ & $.927^{* *}$ & 1.00 & \\
\hline 7 & $\begin{array}{l}\text { Entrepreneurial } \\
\text { intention }\end{array}$ & 3.02 & 1.092 & .022 & -.006 & .047 & $.917^{* *}$ & $.963^{* *}$ & $.955^{* *}$ & 1.00 \\
\hline
\end{tabular}

Correlation is significant at the 0.01 level (2-tailed).**, Correlation is significant at the 0.01 level (2-tailed).*

Model summary: The variance in the entrepreneurial intention explained by the constant and antecedents of entrepreneurial intention was shown in (Table 4). The $R^{2}$ value of implies that $95.9 \%$ of the variation in the dependent variable (entrepreneurial intention) could be explained by the independent variable.

Table 4| Model summary.

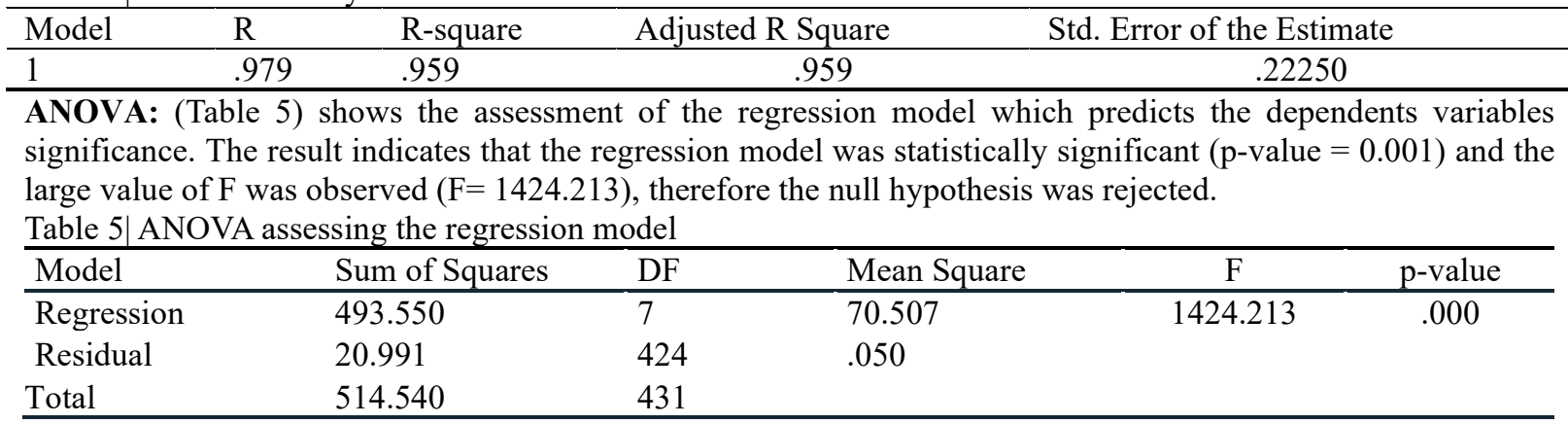

Abbreviations: DF Degree of Freedom; F: F statistic test.

\subsection{The multiple regression results}

The results showed that there was no statistically significant association between the age and entrepreneurial intention $(\beta=-0.002, p<0.883)$. Our finding, revealed that gender $(\beta=-0.077, p<0.001)$ and field of study $(\beta=$ $0.465, \mathrm{p}<0.001)$ was significantly associated with entrepreneurial intention. A statistically significant relationship was found between perceived behavioral control and the intention to start a business $(\beta=0.420, p<$ 0.001). Therefore, our hypothesis was supported (H3). From the results it follows that individuals develop intentions to start a business based on their perceptions of self-efficacy or ability to perform the entrepreneurial behavior. Similarly, a significant association was found between subjective norms and entrepreneurial intention $(\beta=0.524, \mathrm{p}<0.001)$. Therefore, the null hypothesis $(\mathrm{H} 2)$ could be supported. However, non-significant association was found between personal attitude and entrepreneurial intention $(\beta=-0.040 ; p<0.169)$. Therefore, the null hypothesis (H1) could not be supported.

Table 6| Multiple regression models for the final analysis

\begin{tabular}{lllll}
\hline Model & Estimate $(\beta)$ & Std. Error & t-statistic & P-value \\
\hline Constant & 28.241 & 4.341 & 6.505 & .000 \\
Age & -.002 & .007 & -.147 & .883 \\
Gender & -.077 & .037 & -5.283 & .000 \\
Field of study & .465 & .156 & 6.548 & .000 \\
Personal attitude & -.040 & .037 & -1.378 & .169 \\
Subjective norms & .524 & .034 & 15.906 & .000 \\
Perceive behavioral control & .420 & .037 & 12.745 & .000 \\
\hline
\end{tabular}

\section{Discussion}

The study suggests that TPB is the best technique for measuring entrepreneurial intention. Findings revealed that the Sana'a University students have a mild level of entrepreneurial intention. They have future plan for starting their own business someday, and they consider being entrepreneurs as a suitable career path for them. However, we found that the attitude of the students was low, but they preset to have necessary capabilities and skills to start and run a business. Whereas, we found that a dispersion of data points, when assessed with standard deviation, shows that there are considerable differences among students' perceived attitudes toward personal attraction toward entrepreneurship, behavioral control and subjective norms of entrepreneurship.

Several studies reported that personal attitude was the most significant predictor for entrepreneurial intention (Claar et al., 2012; Douglas and Shepherd, 2002; Johns and Mattson, 2005). However, our findings 
were an inverse to the previous study. This may be occurred due to different reasons: (i) sampling error when the data is generated; (ii) social media influence among the participant is different from country to country. On the other hands, our results supported by (Siu and Lo, 2013; Zhang et al., 2015) revealed that attitude fails to generate a significant impact on entrepreneurial intention. There results were in line with our findings. According to TBP the attitude toward a behavior is not only an important factor but also the most determinant among the three in prediction of intention (Autio et al., 1997). We could explain this divergent result because of a lack of entrepreneurial experience among Sana'a university students. Without the entrepreneurial experience, it was difficult for undergraduate students to start a business. So that, it was unlikely to understand the downsides and benefits of being an entrepreneur, and as a result, the variation of attitude towards intention was found.

Consistent with prior studies, we found a significant positive relationship between students' perceived behavioral control and their entrepreneurial intention. Our findings enhance the prior study (Aloulou, 2016), found that a significant positive correlation between entrepreneurial intention and perceived behavioral control. This result was also consistent with the study of (Engle et al., 2010), reported that perceived behavioral control was significant concerning to entrepreneurial intentions in twelve-countries. The individuals who consider themselves capable of carrying out the tasks involved in starting, managing and growing a business are more likely to engage in the activity (Maresch et al., 2016), this was the essence of perceived behavioural control. Also, perceived behavioural control is assumed to reflect past experience as well as anticipated impediments and obstacles (Ajzen, 1991).

The multiple regression models showed a significant positive relationship between students' subjective norms and their entrepreneurial intention. This result was compatible with a study on 3000 business students in Bangalore, India (Krithika and Venkatachalam, 2014), where the result showed a significant relationship between the perceived subjective norms and entrepreneurial intention among participating. Where also, an individual was more likely to start a business if they initiated by a close person (Otuya et al., 2013; Angriawan et al., 2012; Mueller, 2011). This was because if an individual perceives gained from the immediate social setting would approve his/her decision, the prospect of social, emotional and other support would provide extra stimulus to effort the entrepreneurial activity (Mwiya et al., 2017). For a collectivist society like Yemen, the opinions of people to the individual was considered as an important in his/her life to be a business start-up. These findings were in line with a few previous studies (Siu and Lo, 2013; Shinnar and Giacomin, 2012). In contrast, the individualistic societies that place less value on their connectedness with others, their perceptions of what influential people think becomes less influential (Liñán et al., 2011). These findings have not only confirmed the conceptual model hypothesized in this article but they have also helped to show that the TBP is applicable in a developing and collectivist society like Yemen.

\section{Conclusion}

The purpose of this study was to investigate the entrepreneurial intentions of Sana'a university students in Yemen using the concept of theory of planned behaviour. Our study suggested that providing entrepreneurial capabilities among citizens may improve societal norms and individual attitudes toward entrepreneurship. However, we could not found a statistical significant association between attitude and entrepreneurial intention.

Regarding the effect of subjective norms and perceived behavioral control on intention, we found that subjective norms have a slightly higher impact than perceived behavioral control. The difference in the magnitude suggests that subjective norms are the main drive of entrepreneurial intention among university students. Subjective norms reflect the influence of an external environment that may nurture the desire to start a business. Perceived behavioral control reflects an evaluation of internal resources, which addresses the question of what we have and what we can do. We may conclude that the external environment is more important than nature in shaping students' intentions. Finally, we recommend that the government of Yemen and University of Sana'a provide the opportunity of training or workshop for students to improve their attitude towards entrepreneurship. This should be a direction for future studies.

\section{Acknowledgments}

Authors are thankful to the respondents who devoted their time generously to fill out the questionnaires. Our appreciation is also extended to the editor and two anonymous reviewers of European Journal of Business and Management. We are also thankful to all those who offered information and advice on the issue of the entrepreneurial intention of undergraduate students.

\section{Reference}

Adusei, M. (2016). Does entrepreneurship promote economic growth in Africa?. African Development Review, 28 (2), pp. 201-214

Ajzen, I. (1991). The theory of planned behavior. Organizational Behavior and Human Decision Processes,, 50 (2), pp. 179-211. 
Ajzen, I. (2012), The theory of planned behavior. In Lange, P.A.M., Kruglanski, A.W. and Higgins, E.T. (Eds), Handbook of Theories of Social Psychology, Sage, London, pp. 438-459

Alessandro Arrighetti, L. C., Fabio Landini, Nadia Monacelli, (2016). Entrepreneurial intention in the time of crisis: a field study. International Journal of Entrepreneurial Behavior \& Research, 22 (6), pp.835-859.

Aloulou, W. (2016). Predicting entrepreneurial intentions of final year Saudi university business students by applying the theory of planned behavior. Journal of Small Business and Enterprise Development, 23 (4)

Al-Shammari M., Waleed R. 2018. Entrepreneurial intentions of private university students in the kingdom of Bahrain. International Journal of Innovation Science, 10 (1), pp.43-57.

Andre van Stel, Carree, M. and Thurik, A.R. (2005). The effect of entrepreneurial activity on national economic growth. Small Business Economics, 24 (3), pp. 311-321.

Angriawan, A., Conners, S.E., Furdek, J. and Ruth, D. ( 2012). An empirical examination of entrepreneurial intent in the equine industry. Proceedings of the Academy of Entrepreneurship, 18(1), pp. 1-8.

Autio, E., Keeley, R.H., Klofsten, M. and Ulfstedt, T. (1997). Entrepreneurial intent among students: testing an intent model in Asia, Scandinavia, and USA. Frontiers of Entrepreneurial Research. Babson College, Wellesley, MA.

Bujang, M. A., Omar, E. D., \& Baharum, N. A. (2018). A Review on Sample Size Determination for Cronbach's Alpha Test: A Simple Guide for Researchers. Malays J Med Sci, 25(6), pp. 85-99.

Claar, V. V., R. Frey, M. Szarucki, and V. R. TenHaken. ( 2012). Hope for the East: Entrepreneurial Attitudes of MBA Students in Two Transition Economies Relative to Those in the USA. International Journal of Business Excellence, 5, pp. 220-237.

Crant, JM. (1996). The proactive personality scale as a predictor of entrepreneurial intentions. Journal of Small Business Management, 34(3), pp. 42-49

Davidsson, P., (1995). Determinants of entrepreneurial intentions. Jonskoping International Business School.

Debus, M., Tosun, J. and Maxeiner, M. (2017). Support for policies on entrepreneurship and selfemployment among parties and coalition governments. Politics and Policy, 45 (3), pp. 338-371

Douglas, E. J., and D. A. Shepherd. (2002). Self-Employment as a Career Choice: Attitudes, Entrepreneurial Intentions, and Utility Maximization. Entrepreneurial Theory and Practice, 26, 81-90

Engle, R. L., Dimitriadi, N., Gavidia, J.E., Schlaegel, C., Delanoe, S., Alvarado, I., He, X., Buame, S. \& Wolff, B. (2010). Entrepreneurial intent: a twelve-country evaluation of Ajzen's model of planned behaviour. International Journal of Entrepreneurial Behaviour and Research, 16(1), pp. 35-57.

Johns, N., and J. Mattsson. (2005). Destination Development through Entrepreneurship: A Comparison of Two Cases. Tourism Management, 26, pp. 605-616.

Kolvereid, L. (1996). Prediction of employment status choice intentions. Entrepreneurship Theory and Practice, 20 (3), pp. 47-56.

Kolvereid, L., \& Isaksen, E. (2006). New business start-up and subsequent entry into selfemployment. Journal of Business Venturing, 21, pp.866-885.

Krithika, J. and Venkatachalam, B. (2014). A study on impact of subjective norms on entrepreneurial intentions among the business students in Bangalore. Journal of Business and Management, 16(5), pp. 48-50.

Krueger, N. F., Reilly, M.D. \& Carsrud, A.L. (2000). Competing models of entrepreneurial intentions. Journal of Business Venturing, 15, pp. 411-432.

Liñán, F. and Chen, Y.W. (2009). Development and cross-cultural application of a specific instrument to measure entrepreneurial intentions. Entrepreneurship Theory and Practice, 33 (3) pp. 593-617

Liñán, F., and Fayolle, A. (2015). A systematic literature review on entrepreneurial intentions: citation, thematic analyses, and research agenda. International Entrepreneurship and Management Journal, pp. 1-27.

Liñán, F., Urbano, D. \& Guerrero, M. (2011). Regional variations in entrepreneurial cognitions: start-up intentions of university students in Spain Regional Development. Entrepreneurship and, 23(3), pp. 187-215

Malebana, J. (2014). Entrepreneurial intentions of South African rural university students: A test of the theory of planned behaviour. Journal of Economics and Behavioral Studies, 6, (2), pp. 130-143.

Malebana, M. J. (2017). Knowledge of entrepreneurial support and entrepreneurial intention in the rural provinces of South Africa. Development Southern Africa, DOI: 10.1080/0376835X.0372016.1259990.

Maria Saberi, and Allam Hamdan, (2018). The moderating role of governmental support in the relationship between entrepreneurship and economic growth: A study on the GCC countries. Journal of Entrepreneurship in Emerging Economies. https://doi.org/10.1108/JEEE-10-2017-0072

Maresch, D., Harms, R., Kailer, N. and Wimmer-Wurm, B. (2016), The Impact of Entrepreneurship Education on the Entrepreneurial Intention of Students in Science and Engineering versus Business Studies University Programs. Technological Forecasting and Social Change, 104, pp.172-179.

Moriano, J. A., Gorgievski, M., Laguna, M., Stephan, U., \& Zarafshani, K. (2012). A cross-cultural approach to understanding entrepreneurial intention. Journal of Career Development, 39(2), pp.162-185.

Mueller, S. (2011). Increasing entrepreneurial intention: effective entrepreneurship course characteristics. 
International Journal of Entrepreneurship and Small Business, 13 (1), pp. 55-74.

Mwiya, D., Wang, Y., Shikaputo, C., Kaulungombe, B., \& Kayekesi, M. (2017). Predicting the entrepreneurial intentions of university students: Applying the theory of planned behaviour in Zambia, Africa. Open Journal of Business and Management, (5), pp. 592-610

Otuya, R., Kibas, P., Gichira, R. and Martin, W. (2013). Entrepreneurship education: influencing students' entrepreneurial intentions. International Journal of Innovative Research and Studies, 2 (4), pp. 132-148.

Reyad, S., Badawi, S. and Hamdan, A. (2018). Entrepreneurship and accounting students' career in arab region: conceptual perspective. The Journal of Developing Areas, 52 (4), pp. 283-288.

Schwarz, E. J., Wdowiak, M. A., Almer-Jarz, D. A. \& Breitenecker, R. J. (2009). The effects of attitudes and perceived environment conditions on students' entrepreneurial intent Education \& Training, . An Austrian perspective, 51(4), pp. 272-291

Shah, N. and Soomro, B. (2017). Investigating entrepreneurial intention among public sector university students of Pakistan. Education p Training, 59 (7/8), pp. 841-855.

Sharaf, A., El-Gharbawy, A. and Ragheb, M.A. (2018). Factors That Influence Entrepreneurial Intention within University Students in Egypt. Open Access Library Journal, 5, e4881.

Shinnar, R. and Giacomin, O. (2012) Entrepreneurial Perceptions and Intentions: The Role of Gender and Culture. Entrepreneurship Theory and Practice, 36, pp. 465-493

Siu, W., and E. S. Lo. 2013. Cultural Contingency in the Cognitive Model of Entrepreneurial Intention. Entrepreneurship Theory and Practice 37(2), pp.147-73

Thompson, E. R. (2009). Individual entrepreneurial intent: construct clarification and development of an internationally reliable metric. Entrepreneurship Theory and Practice, pp. 669-694.

Van Gelderen, M., Brand, M., Van Praag, M., Bodewes, W., Poutsma, E., \& Van Gils, A. (2008). Explaining entrepreneurial intentions by means of the theory of planned behaviour. Career Development International, 13(6), pp. 538-559

Wiedermann, W., \& von Eye, A. (2015). Direction of Effects in Multiple Linear Regression Models. Multivariate Behav Res, 50(1), pp. 23-40.

Yamane, Taro (1967). Statistics: An Introductory Analysis. 2nd Edition. New York, Harper and Row.

Zhang, P., Wang, DD, Owen, CL. (2015). A study of entrepreneurial intention of university students. Entrepreneurship Research Journal, 5(1), pp. 61-82. 